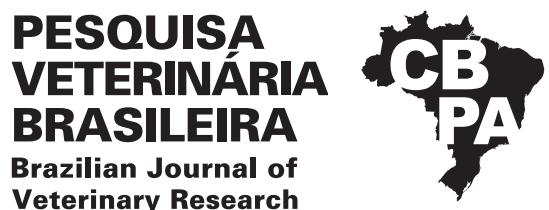

Pesq. Vet. Bras. 41:e06988, 2021 DOI: 10.1590/1678-5150-PVB-6988

Original Article inarv Research

ISSN 0100-736X (Print)

ISSN 1678-5150 (Online)

\title{
Spontaneous poisoning by Dodonaea viscosa (Sapindaceae) in cattle in Southern Brazil ${ }^{1}$
}

\author{
Rosimeri Zamboni²* (D), Taina S. Alberti² (D), Fabiano R. Venancio ${ }^{2}$ (D), \\ Lucas S. Quevedo ${ }^{3}$, Josiane Bonel ${ }^{2}$, Margarida B. Raffi², Ana L. Schild ${ }^{2}$ \\ and Eliza S.V. Sallis ${ }^{2}$ (D)
}

\begin{abstract}
Zamboni R., Alberti T.A., Venancio F.R., Quevedo L.S., Bonel J., Raffi M.B., Schild A.L. \& Sallis S.V. 2021. Spontaneous poisoning by Dodonaea viscosa (Sapindaceae) in cattle in southern Brazil. Pesquisa Veterinária Brasileira 41:e06988, 2021. Laboratório Regional de Diagnóstico, Departamento de Patologia Animal, Faculdade de Veterinária, Universidade Federal de Pelotas, Rua Gomes Carneiro 1, Centro, Pelotas, RS 96010-610, Brazil. E-mail: rosi_zamboni@yahoo.com.br

In this study, an outbreak of spontaneous poisoning by Dodonaea viscosa (D. viscosa) in a herd of dairy cattle in the municipality of Capão do Leão, Rio Grande do Sul, was investigated. Three deaths occurred in a batch of 16 Jersey cattle, aged between three and four years, kept in a native field. The clinical signs observed were apathy, decreased production, and anorexia, with death occurring within approximately $48 \mathrm{~h}$ after the onset of signs. The three cattle were necropsied, and tissue samples were sent for histopathological examination. Necropsy findings included serosanguineous fluid in the abdominal cavity, intestines with congested serosa, and marked mesenteric edema. The mucosa of the abomasum of two of the animals was hemorrhagic with bloody content, and among the ruminal content of a bovine, leaves with morphological characteristics compatible with D. viscosa were observed. The livers of the three animals were enlarged, with accentuation of the lobular pattern. Histologically, centrilobular coagulation necrosis with congestion and hemorrhage was observed in the liver. Vacuolization and degeneration of hepatocytes were observed in the mid-zonal and periportal regions. The diagnosis of poisoning by $D$. viscosa leaves was based on epidemiological data, necropsy findings, and histopathological alterations. The presence of the plant in the rumen and in the grazing site of the affected cattle was essential for the diagnosis.
\end{abstract}

INDEX TERMS: Spontaneous poisoning, Dodonaea viscosa, Sapindaceae, cattle, Brazil, acute hepatotoxicity, disease of cattle, poisonous plants, liver necrosis.

RESUMO.- [Intoxicação espontânea por Dodonaea viscosa (Sapindaceae) em bovinos no sul do Brasil.] Neste trabalho, é descrito um surto de intoxicação espontânea por Dodonaea viscosa (D. viscosa) ocorrido em um rebanho de bovinos leiteiros, no município de Capão do Leão, no Rio Grande do Sul. Ocorreram três mortes em um lote de 16 bovinos da raça Jersey com idades entre três e quatro anos, mantidos em campo

\footnotetext{
${ }^{1}$ Received on July 14, 2021.

Accepted for publication on August 24, 2021.

${ }^{2}$ Laboratório Regional de Diagnóstico, Departamento de Patologia Animal, Faculdade de Veterinária, Universidade Federal de Pelotas (UFPel), Rua Gomes Carneiro 1, Centro, Pelotas, RS 96010-610, Brazil. *Corresponding author: rosi_zamboni@yahoo.com.br

${ }^{3}$ Departamento de Patologia Animal, Centro de Ciências Agroveterinárias, Universidade do Estado de Santa Catarina (UDESC), Av. Luiz de Camões 2090, Conta Dinheiro, Lages, SC 88520-000, Brazil.
}

nativo. Os sinais clínicos observados foram apatia, queda na produção e anorexia, com morte em aproximadamente 48 horas após o início dos sinais. Os três bovinos foram necropsiados, e amostras de tecidos foram encaminhadas para exame histopatológico. Os achados de necropsia incluíam líquido serossanguinolento na cavidade abdominal, intestinos com serosas congestas e marcado edema de mesentério. A mucosa do abomaso de dois animais apresentava-se hemorrágica com conteúdo sanguinolento e, em meio ao conteúdo ruminal de um bovino foram observadas folhas com caracteres morfológicos compatíveis com $D$. viscosa. 0 fígado dos três animais estava aumentado, com acentuação do padrão lobular. Histologicamente no fígado havia necrose de coagulação centrolobular com congestão e hemorragia. Nas regiões médio-zonal e periportal observou-se vacuolização e degeneração dos hepatócitos. 0 diagnóstico de intoxicação 
pelas folhas $D$. viscosa foi baseado nos dados epidemiológicos, nos achados de necropsia e nas alterações histopatológicas. A presença da planta no rúmen e no local de pastoreio dos bovinos afetados foi fundamental para o diagnóstico.

TERMOS DE INDEXAÇÃO: Intoxicação espontânea, Dodonaea viscosa, Sapindaceae, bovinos, Brasil, hepatotoxicidade aguda, doença de bovinos, plantas tóxicas, necrose hepática.

\section{INTRODUCTION}

Dodonaea viscosa (D. viscosa) is a native plant of the Sapindaceae family, popularly known as hopbush, red broom, field broom, deerweed, and red hurdle (Tokarnia et al. 2012). The center of origin of Dodonaea viscosa is believed to be Australia, and it is found in all tropical and subtropical regions of the world (Al-Snafi 2017). In Brazil, it is the most abundant shrub species in the Pampa biome, occurring mainly along the coastline, in restingas, plains, and mountain slopes, and is considered a pioneer species of little demand owing to its edaphic characteristics and recovery of degraded areas (Paoli \& Sarti 2008, Tokarnia et al. 2012, Carlucci et al. 2015).

The plant has numerous known active properties that are of therapeutic and medicinal importance (Kumar et al. 2013, Al-Snafi 2017). However D. viscosa has been associated with acute liver failure in cattle, and its toxic effects have not been determined (Colodel et al. 2003, Cattani et al. 2004, Tokarnia et al. 2012). In Brazil, only one outbreak of spontaneous poisoning was related to the ingestion of D. viscosa in cattle in the state of Rio Grande do Sul (Colodel et al. 2003).

Due to the wide distribution of $D$. viscosa in southern Brazil (Tokarnia et al. 2012), there is a scarcity of reports on intoxication and clinical-pathology similar to other acute hepatotoxicosis in cattle. The present study aimed to describe an outbreak of spontaneous poisoning in cattle, which ingested the leaves of $D$. viscosa during their flowering phase in the southern region of Rio Grande Sul.

\section{MATERIALS AND METHODS}

Three dairy cattle were necropsied on the farm and sent to the "Laboratório Regional de Diagnóstico" (LRD) of the "Faculdade de Veterinária", "Universidade Federal de Pelotas" (UFPel). Fragments of all organs were fixed in 10\% buffered formalin. After 48 hours of fixation, the samples were cleaved, processed routinely, cut into $3 \mu \mathrm{m}$ thick sections, and stained using routine hematoxylin and eosin (HE) technique. Plant specimens were collected and sent for identification at the Herbarium of the "Departamento de Botânica" of the "Instituto de Biologia", UFPel (Herbário Pel). Epidemiological and clinical data were obtained during visits to the property where the outbreak happened.

\section{RESULTS}

The outbreak of spontaneous poisoning by Dodonaea viscosa occurred in April 2016 in a rural dairy farm located in the municipality of Capão do Leão ( $31^{\circ} 74^{\prime} 88.25^{\prime \prime}$ S, 52 $2^{\circ} 54^{\prime} 32.11^{\prime \prime}$ W), Rio Grande do Sul. Among the batch of 16 lactating Jersey cows aged three-four years old, three animals showed apathy, decreased production, and anorexia, and died approximately 48 hours after the onset of clinical signs. The cattle in this lot were in native field paddocks with low forage supply, surrounded by areas of native forest (paddocks divided into an average of $5 \mathrm{ha}$ ), in which they rotated when they started lactation. In the paddock where the deaths occurred, $D$. viscosa was observed to be present (Fig.1-2), and no other hepatotoxic agents was present. Samples of D. viscosa were sent to Herbário Pel, identified, and deposited according to the fall number PEL $N^{\circ} 27.064$.

Serosanguineous fluid was observed in the abdominal cavity during necropsy of the three affected cattle. The intestines presented a congested serous with marked edema of the mesentery (Fig.3), and there was hemorrhagic content in the lumen of the small intestine. The mucosa of the abomasum of the two animals was hemorrhagic with bloody content (Fig.4). Amid the ruminal content of the bovine, leaves with morphological characteristics compatible with $D$. viscosa were observed. The livers of the three animals were enlarged, with accentuation of the lobular pattern, and the gallbladder was
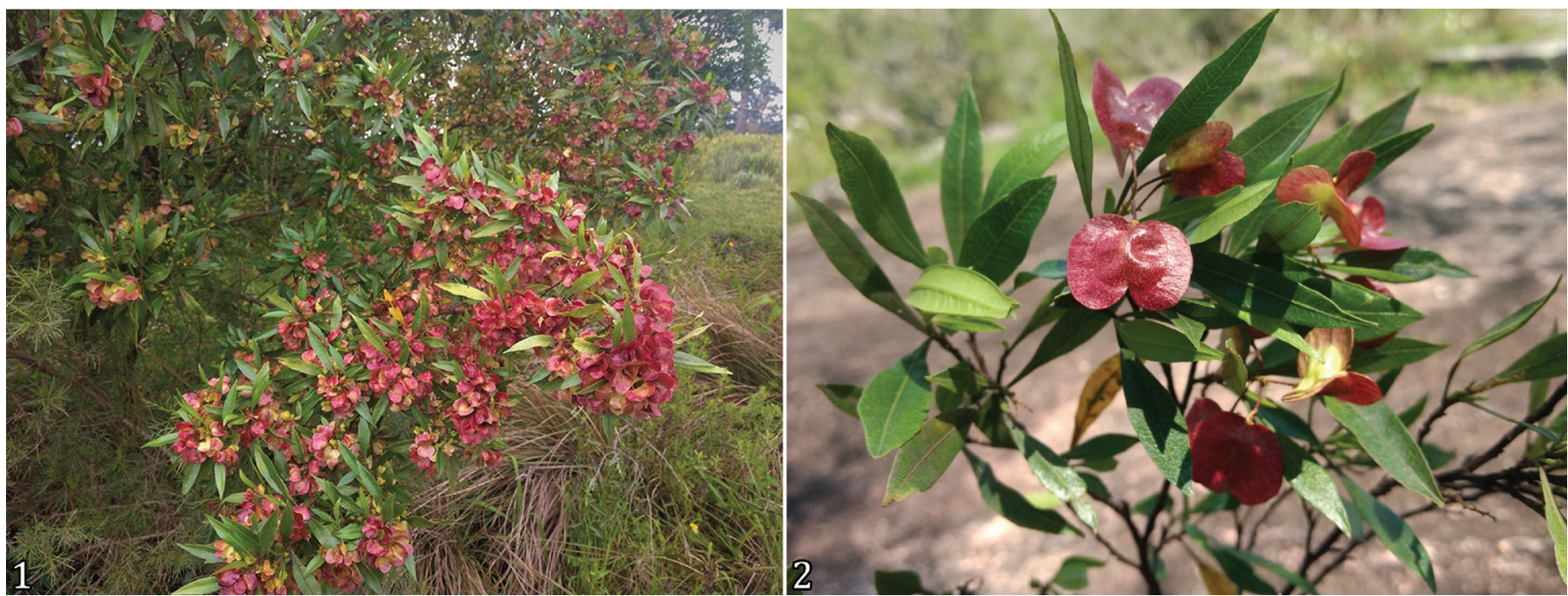

Fig.1-2. Exemplary of Dodonea viscose located in the municipality of Capão do Leão (3174'88.25” S, 52 $54^{\prime} 32.11^{\prime \prime}$ W). (1) Large shrub of D. viscosa approximately $2 \mathrm{~m}$ tall in fruiting. (2) Detail of simple and alternate leaves with fruits with three to four wings. 
filled with wall edema (Fig.5 and 6). Histologically, centrilobular coagulation necrosis with congestion and hemorrhage was observed in the liver (Fig.7). Vacuolization and degeneration of hepatocytes were observed in the mid- and periportal regions (Fig.8).

\section{DISCUSSION AND CONCLUSIONS}

The diagnosis of poisoning by Dodonaea viscosa leaves was based on macroscopic and histopathological findings, as well as the presence of the plant in the rumen and grazing site of the affected cattle. The acute liver injury observed in the cattle, which caused the death of the animals, is a characteristic of toxic liver diseases in the species. However, the identification of the hepatotoxic agent is the limiting epidemiological factor for the definitive diagnosis of the cause of acute liver failure (Tokarnia et al. 2012, Alberti et al. 2020).

The main differential diagnoses considered in this outbreak were Xanthium spp., Cestrum parqui, Cestrum corymbosum, Cestrum intermedium, Trema micranta, and Perreya flavipes larvae (Cattani et al. 2004, Soares et al. 2008, Tokarnia et al.
2012, Alberti et al. 2020), which are important hepatotoxic agents frequently diagnosed in the southern region of Rio Grande do Sul. Based on the acute and non-specific clinical symptoms shown by the cattle, the bovine parasitic sadness complex should be considered as a differential symptom in these cases owing to the endemic characteristic of the disease in Rio Grande do Sul (Estima-Silva et al. 2016). In these cases, epidemiological data, presence of the plants, necropsy, and histopathology are essential for the definitive diagnosis and prevention of poisoning by D. viscosa (Tokarnia et al. 2012, Alberti et al. 2020).

Epidemiological data on toxicity of the plant are scarce, as cases of spontaneous poisoning have been described (Colodel et al. 2003) in cattle. In a study carried out in rats (higher dose of $1250 \mathrm{mg} / \mathrm{kg}$ ), there were no signs of acute toxicity by D. viscosa (Arun \& Asha 2008). Cattani et al. (2004) demonstrated that the leaves of $D$. viscosa were toxic to cattle during budding (June), inflorescence (September/October), and dry stages. The present case occurred in April, considering the flowering period of D. viscosa (Carvalho 2014); moreover, the leaves of $D$. viscosa were toxic at different phases.
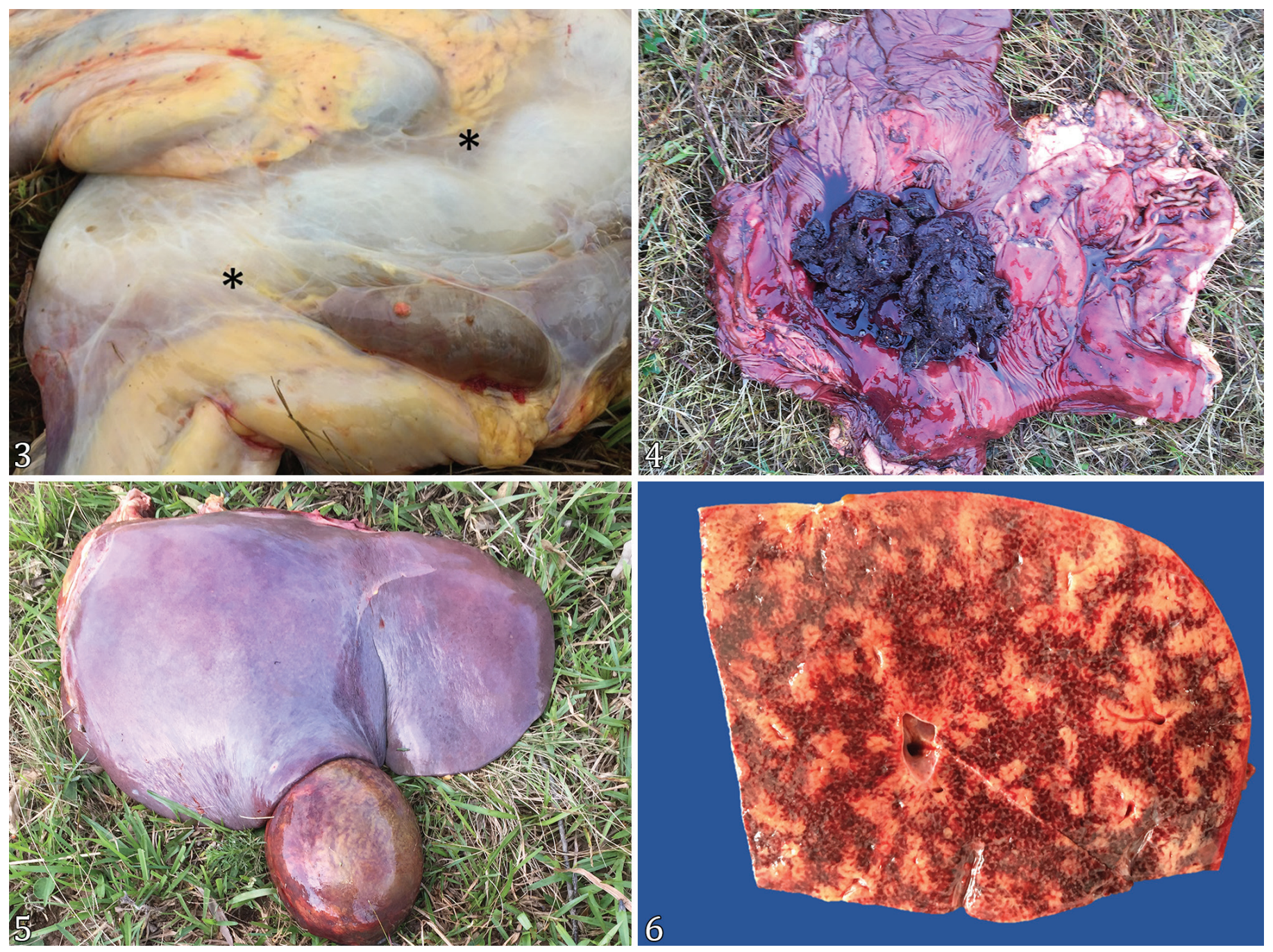

Fig.3-6. Macroscopic findings of cattle poisoned by Dodonea viscosa. (3) Mesentery edema (asterisks). (4) Abomasum with abundant bloody material and hemorrhagic mucosa. (5) Mild diffuse hepatomegaly and increased gallbladder volume. (6) Hepatic surface with accentuated lobular pattern, characterized by dark red areas interspersed with lighter areas. 

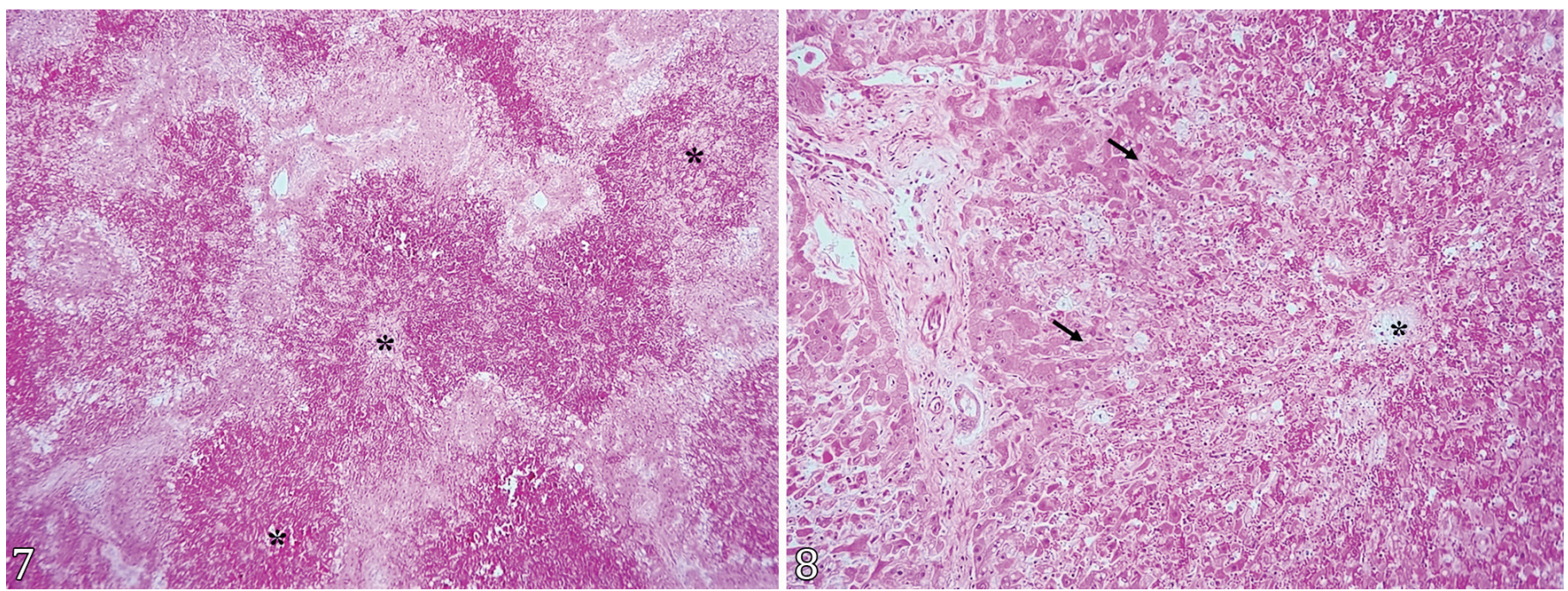

Fig.7-8. Hepatic histopathological lesion in cattle poisoned by Dodonea viscosa. (7) Marked coagulation necrosis and centrilobular to medizonal hemorrhage, with occasional bridging (asterisks). HE, obj.4x. (8) Centrilobular necrosis (asterisk) with degeneration and vacuolization of hepatocytes (arrows) in the mediozonal and periportal regions. HE, obj.10x.

It is believed that the cattle accidentally ingested the leaves as a result of low supply of forage combined with the high stocking density in the paddock (approximately 3.5 cattle per hectare). Due to the wide geographic distribution of $D$. viscosa, mainly in the southern region of Brazil, this should be considered as a differential diagnosis in acute hepatotoxicosis in cattle. Furthermore, the presence of the plant in the rumen and grazing site of affected cattle is essential for the definitive diagnosis of spontaneous poisoning by $D$. viscosa.

Conflict of interest statement.- The authors have no competing interests.

\section{REFERENCES}

Alberti T.S., Zamboni R., Scheid H.V., Venancio F.R., Brunner C.B., Raffi M.B., Schild A.L. \& Sallis E.S.V. 2020. Intoxicação espontânea por brotos de Xanthium spp. em bovinos no sul do Rio Grande do Sul. Acta Scient. Vet. 48(Supl.1):507. <https://dx.doi.org/10.22456/1679-9216.99161>

Al-Snafi A.E. 2017. A review on Dodonaea viscosa: a potential medicinal plant. J. Pharm. 7(2):10-21. <https://dx.doi.org/10.9790/3013-0702011021>

Arun M. \& Asha V.V. 2008. Gastroprotective effect of Dodonaea viscosa on various experimental ulcer models. J. Ethnopharmacol. 118(3):460-465. <https://dx.doi.org/10.1016/j.jep.2008.05.026><PMid:18603387>

Carlucci M.B., Bastazini V.A.G., Hofmann G.S., Macedo J.H., Iob G., Duarte L.D.S., Hartz S.M. \& Müller S.C. 2015. Taxonomic and functional diversity of woody plant communities on opposing slopes of inselbergs in southern Brazil. Plant. Ecol. Divers. 8(2):187-197. <https://dx.doi.org/10.1080/1 7550874.2014.955544>
Carvalho P.E.R. 2014. Espécies Arbóreas Brasileiras. Embrapa, Brasília. 634p.

Cattani C.S.O., Colodel E.M., Traverso S.D., Correa A.M.R. \& Driemeier D. 2004. Intoxicação experimental por Dodonea viscosa (Sapindaceae) em bovinos. Pesq. Vet. Bras. 24(1):31-34. <https://dx.doi.org/10.1590/ S0100-736X2004000100008>

Colodel E.M., Traverso S.D., Seitz A.L., Correa A., Oliveira F.N., Driemeier D. \& Gava A. 2003. Spontaneous poisoning by Dodonea viscosa (Sapindaceae) in cattle. Vet. Human Toxicol. 45(3):147-148. <PMid:12776792>

Estima-Silva P., Molarinho K.R., Marcolongo-Pereira C., Soares M.P., Sallis E.S.V., Ladeira S.R.L. \& Schild A.L. 2016. Morte súbita em bovinos no Sul do Rio Grande do Sul: epidemiologia e diagnóstico. Pesq. Vet. Bras. 36(1):19-23. <https://dx.doi.org/10.1590/S0100-736X2016000100003>

Kumar M.S., Selvakumar S., Rao M.R.K. \& Anbuselvi S. 2013. Preliminary phytochemical analysis of Dodonaea viscosa leaves. Asian J. Plant Sci. $3(1): 43-46$.

Paoli A.A.S. \& Sarti J. 2008. Morfoanatomia e desenvolvimento de frutos e sementes de Dodonea viscosa (L.) Jacquin (Sapindaceae). Revta Bras. Sementes 30(2):33-42. <https://dx.doi.org/10.1590/S0101-31222008000200005>

Soares M.P., Quevedo P.S. \& Schild A.L. 2008. Intoxicação por larvas de Perreyia flavipes em bovinos na região sul do Rio Grande do Sul. Pesq. Vet. Bras. 28(3):169-173.<https://dx.doi.org/10.1590/S0100-736X2008000300007>

Tokarnia C.H., Brito M.F., Barbosa J.I.D., Peixoto P.V. \& Döbereiner J. 2012. Plantas Tóxicas do Brasil para Animais de Produção. 2a ed. Helianthus, Rio de Janeiro. 566p. 